\title{
Penerapan Model Ekspository Dengan Menggunakan Metode Demontrasi Dan Pemberian Tugas Untuk Meningkatkan Prestasi Belajar
}

\author{
I Nyoman Mulyadi \\ SMP Negeri 3 Selat \\ celipuyr@gmail.com
}

DOI : $10.37329 /$ cetta.v3i1.408

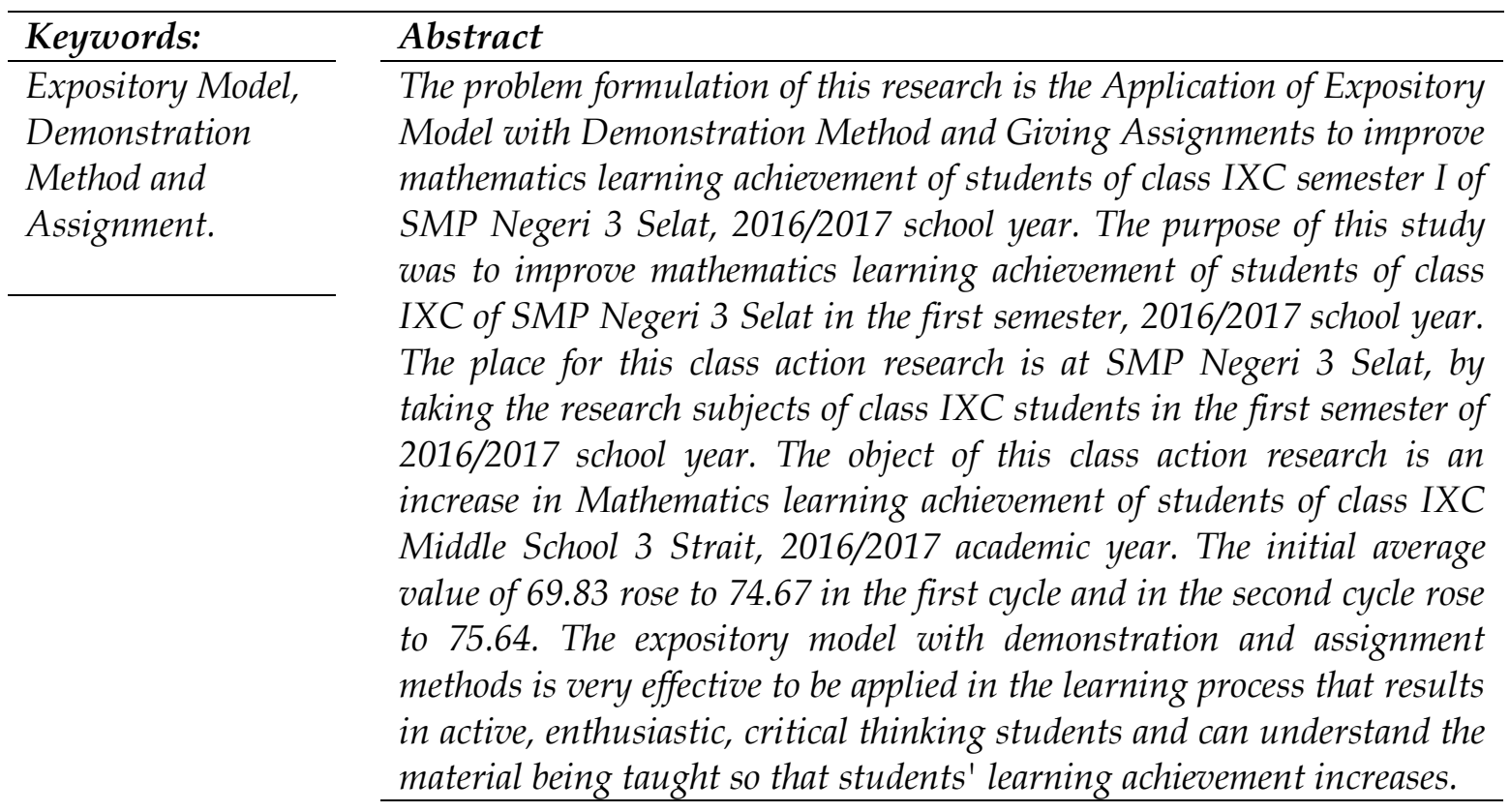

\begin{tabular}{l}
\hline Kata kunci: \\
\hline Model \\
Ekspository, \\
Metode \\
Demontrasi dan \\
Pemberian \\
Tugas. \\
\hline
\end{tabular}

\begin{tabular}{l} 
Abstrak \\
\hline Rumusan masalah penelitian ini adalah penerapan model \\
Ekspository dengan metode demontrasi dan pemberian tugas \\
untuk meningkatkan prestasi belajar Matematika siswa kelas IXC \\
semester I SMP Negeri 3 Selat, tahun pelajaran 2016/2017. Tujuan \\
penelitian ini adalah untuk meningkatkan prestasi belajar \\
Matematika siswa kelas IXC SMP Negeri 3 Selat pada semester I, \\
tahun pelajaran 2016/2017. Tempat penelitian tindakan kelas ini \\
adalah di SMP Negeri 3 Selat, dengan mengambil subjek \\
penelitian siswa kelas IXC pada semester I tahun pelajaran \\
2016/2017. Objek penelitian tindakan kelas ini adalah \\
peningkatan prestasi belajar Matematika siswa kelas IXC SMP \\
Negeri 3 Selat, tahun pelajaran 2016/2017. Nilai rata-rata awal \\
69,83 naik menjadi 74,67 pada siklus I dan pada siklus II naik \\
menjadi 75,64. Model ekspository dengan metode demontrasi
\end{tabular}


dan pemberian tugas sangat efektif diterapkan dalam proses pembelajaran yang mengakibatkan siswa aktif, antusias, berpikir kritis dan dapat memahami materi yang diajarkan sehingga prestasi belajar siswa menjadi meningkat.

\section{Pendahuluan}

Upaya meningkatkan prestasi belajar siswa seperti penguasaan metode-metode ajar, penguasaan model pembelajaran, penguasaan teori-teori belajar, penguasaan teknikteknik tertentu, penguasaan peran, fungsi serta kegunaan mata pelajaran. Prestasi belajar matematika yang lebih baik, motivasi berprestasi tinggi, sedang atau rendah, dan gaya belajar visual, auditorial atau kinestetik serta untuk mengetahui ada atau tidaknya interaksi antara motivasi berprestasi dan gaya belajar siswa terhadap prestasi belajar (Nurhidayah, 2015). Apabila guru menguasai dan mengerti tentang hal-hal tersebut dapat diyakini bahwa prestasi belajar peserta didik pada mata pelajar Matematika tidak akan rendah. Namun, kenyataannya prestasi belajar siswa kelas IX C semester I tahun ajaran 2016/2017 yaitu siswa yang tuntas baru mencapai 45,16\% dengan rata - rata 69,83. Hal ini jauh di bawah harapan, mengingat KKM mata pelajaran ini adalah 70 sedangkan ketuntasn belajar yang dituntut adalah $80 \% \geq$. Terjadinya kesenjanga antara harapanharapan yang telah disampaikan dengan kenyataan lapangan yang jauh berbeda. Perhatian orangtua, motivasi belajar dan lingkungan sosial secara bersama-sama memberikan pengaruh yang signifikan terhadap prestasi belajar (Kurniawan \& Wustqa, 2014). Dalam upaya memperbaiki mutu pendidikan utama pada mata pelajaran Matematika, sangat perlu kiranya dilakukan perbaikan cara pembelajaran. Salah satunya adalah perbaikan pembelajaran dengan menngunakan model pembelajran model Ekspository dengan metode demontrasi dan pemberian tugas.

Pengertian prestasi yang disampaikan oleh para ahli sangatlah bermacammacam dan bervariasi. Hal ini disebabkan sudut pandang yang bebeda dari para ahli itu sendiri. Perbedaan itu justru dapat saling melengkapi tentang pengertian prestasi. Menurut Zaenal Arifin ( 2012:3 ) prestasi adalah hasil dari kemampuan, keterampilan dan sikap seseorang dalam menyelesaikan suatu hal. Prestasi adalah hasil yang telah dicapai ( dari yang telah dilakukan, dikerjakan, dan sebagainya.) Menurut Bustalin (2004:3) bahwa prestasi adalah penilaian pendidikan tentang perkembangan dan kemajuan murid yang berkenaan dengan penguasaan bahan pelajaran yang disajikan kepada mereka dan nilai. Pada hakikatnya belajar adalah suatu proses yang ditandai dengan adanya perubahan 
pada diri seseorang. Perubahan sebagai hasil proses belajar dapat ditunjukkan dengan berbagai bentuk seperti berubahnya pengetahuan, pemahaman, sikap dan tingah lakunya keterampilan, kecakapan dan kemampuannya, dan aspek-aspek lain yang ada pada idividu tersebut. Belajar merupakan perubahan tingkah laku atau penampilan dengan serangkaian kegiatan misalnya dengan membaca, mengamati, mendengarkan, meniru dan sebagainya. Belajar juga akan lebih baik kalau subyek belajar itu mengalami atau melakukannya. Jadi, tidak bersifat verbalistik.

\section{Metode}

Tempat penelitian tindakan kelas ini adalah di SMP Negeri 3 Selat, dengan mengambil subjek penelitian siswa kelas IXC pada semester I tahun pelajaran 2016/2017. Penelitian ini dibagi dalam dua siklus dengan masing - masing siklus terdiri dari empat tahapan yaitu: 1) Perencanaan,2) Tindakan, 3) Observasi/Evaluasi, dan 4) Refleksi.

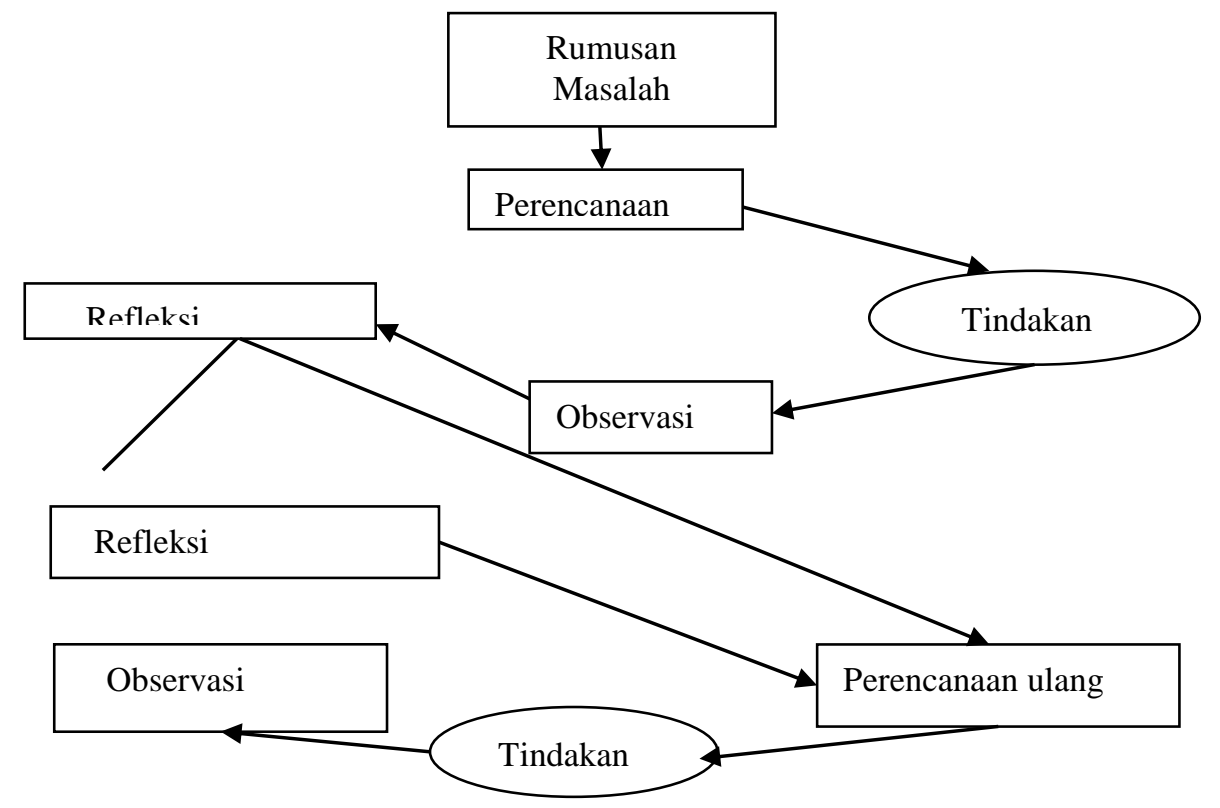

Gambar 1 Prosedur Penelitian

\section{Hasil dan Pembahasan}

\section{Hasil Penelitian}

Hasil pelaksanaan penelitian akan dijabarkan secara detail siklus demi siklus. Penjabarannya dilengkapi dengan data-data dan tindakan mulai dari perencanaan, pelaksanaan, pengamatan dan refleksi. Pembahasan hasil penelitian difokuskan pada prestasi belajar siswa. Perbandingan prestasi belajar Matematika siswa kelas IXC SMP Negeri 3 Selat semester I tahun pelajaran 2016/2017, seperti tabel berikut ini. 
Tabel 1 Perbandingan Hasil Belajar Siswa IXC SMP Negeri 3 Selat

Semester I Tahun Pelajaran 2016/2017 Siklus I dan Siklus II.

\begin{tabular}{|l|l|l|l|l|}
\hline No. & Aspek & Siklus I & Siklus II & $\begin{array}{l}\text { Keterangan } \\
\text { (KKM 70) }\end{array}$ \\
\hline 1. & Jumlah & 2315 & 2345 & Meningkat \\
\hline 2. & Rata-Rata & 74,67 & 75,64 & Meningkat \\
\hline 3. & Daya Serap & $74,67 \%$ & $75,64 \%$ & Meningkat \\
\hline 4. & Jumlah Siswa Remidial & 11 & 6 & Menurun \\
\hline 5. & Jumlah Siswa Pengayaan & 20 & 25 & Meningkat \\
\hline 6. & Ketuntasan Klasikal & $64,51 \%$ & $80,64 \%$ & Meningkat \\
\hline
\end{tabular}

Untuk lebih memperjelas perbandingan prestasi belajar siswa kelas IXB SMP

Negeri 3 Selat semester I tahun pelajaran 2018/2019, juga disajikan dalam bentuk grafik perbandingan prestasi belajar pada siklus I dan siklus II, seperti pada grafik berikut ini.

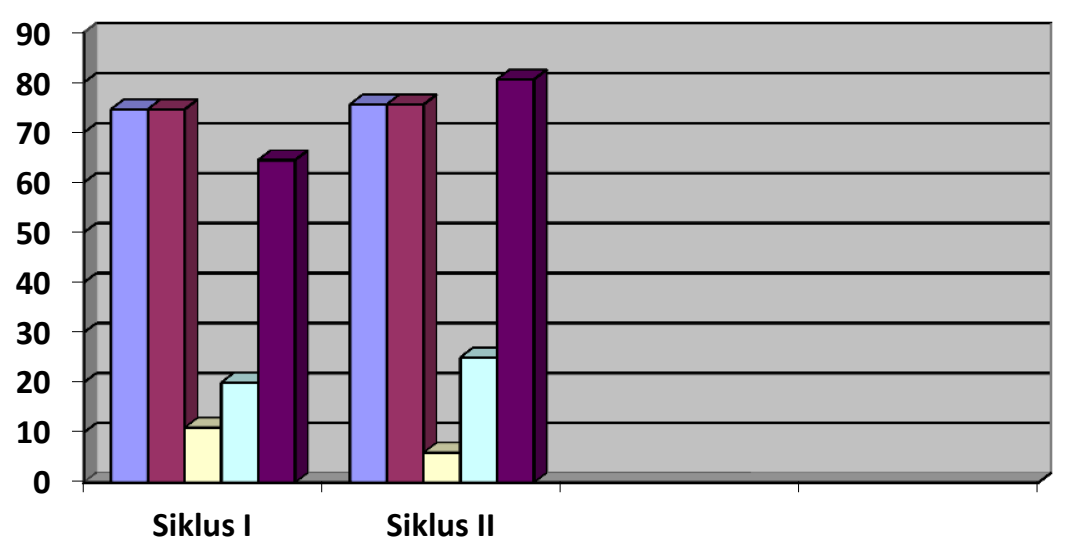

\begin{tabular}{|l|}
\hline Rata-rata \\
$\square$ Daya Serap \\
$\square$ Jlh Siswa Remidi \\
$\square$ Jlh Siswa Pengayaan \\
$\square$ Ketuntasan Klasikal
\end{tabular}

Gambar 2 Grafik Perbandingan Prestasi Belajar Matematika Siswa Siklus I dan Siklus II

\section{Pembahasan}

Berdasarkah hasil pengamatan selama pelaksanaan penelitian tindakan kelas pada siklus I ada berapa hal yang perlu dijelaskan dalam pembahasan ini diantaranya hasil tes prestasi belajar yang merupakan tes uraian memforsir siswa untuk betul-betul dapat memahami apa yang sudah dipelajari. Dengan melakukan penelitian tindakan kelas, guru mampu memperbaiki proses pembelajaran melalui kajian terhadap apa yang terjadi di kelasnya (Widayati, 2014). Nilai rata-rata siswa di siklus I sebesar 74,67 menunjukkan bahwa siswa setelah menguasai materi yang diajarkan walaupun belum begitu sempurna. Hasil ini menunjukkan peningkatan kemampuan siswa menguasai mata pelajaran 
Matematika. Apabila dibandingkan dengan nilai awal siswa sesuai data yang sudah disampaikan dalam analisis sebelumnya. Hasil belajar peserta didik akan terjawab dengan baik dengan sisitem penilaian yang baik (Sudjana, 2009). Hasil tes prestasi belajar di siklus I telah menemukan efek utama bahwa penggunaan model/metode tertentu akan berpengaruh terhadap prestasi belajar siswa yang dalam hal ini adalah Penerapan Model Ekspositoty dengan Metode Demontrasi dan Pemberian Tugas untuk meningkatkan prestasi belajar Matematika siswa kelas IXC SMP Negeri 3 Selat semester I tahun pelajara 2016/2017.

Seperti telah diketahui bersama bahwa mata pelajaran Matematika menitikberatkan pembelajaran pada aspek kognitif, afektif dan psikomotorik sebagai pedoman prilaku kehidupan sehari-hari siswa. Kemampuan siswa pada ranah kognitif, afektif dan psikomotorik materi optik; mengetahui perbedaaan kemampuan antara siswa laki-laki dengan siswa perempuan pada setiap ranah penilaian; serta keterkaitan antara kemampuan ranah afektif dengan ke- mampuan ranah kognitif dan kemampuan ranah psikomotorik (Rosa, 2015). Untuk penyelesaian kesulitan yang ada maka penggunaan model Ekspositoty dengan metode demontrasi dan pemberian tugas ini dapat membantu siswa untuk bertindak aktif memecahkan masalah yang ada bersama dengan anggota kelompoknya. Hal inilah yang membuat siswa berpikir lebih kreatif dan kritis sehingga mampu untuk memecahkan tugas -tugas yang kompleks dan efek selanjutnya adalah para siswa akan dapat memahami dan meresapi mata pelajaran Matematika lebih jauh. Kegiatan guru dalam pembelajaran adalah melatih dan membimbing siswa berpikir kritis dan kreatif dalam menyelesaikan masalah (Sinambela, 2013). Kendala yang masih tersisa yang perlu dibahas adalah prestasi belajar yang dicapai pada siklus I ini belum memenuhi harapan sesuai dengan tuntutan KKM mata pelajaran Matematika di SMP Negeri 3 Selat pada semester I Tahun pelajaran 2016/2017 ini yaitu 70. Oleh karena itu, upaya perbaikan lebih lanjut masih perlu diupayakan sehingga perlu dilakukan perencanaan yang lebih matang untuk siklus selanjutnya.

Hasil yang diperoleh dari tes prestasi belajar di siklus II menunjukkan bahwa kemampuan siswa dalam mengikuti pelajaran sudah cukup baik. Ini terbukti dari ratarata nilai siswa mencapai 75,64. Hasil ini menunjukkan bahwa model Ekspositoty dengan metode demontrasi dan pemberian tugas telah berhasil meningkatkan prestasi belajar Matematika siswa kelas IX C. Hasil penelitian ini membuktikan bahwa penerapan model Ekspository dengan metode demontrasi dan pemberian tugas yang diterapkan dalam 
proses pembelajaran Matematika meningkatkan prestasi belajar siswa. Prestasi yang dicapai siswa membuktikan bahwa guru sudah tepat memilih model Ekspository dengan metode demontrasi dan pemberian tugas dalam melaksanakan proses pembelajaran di kelas. Setelah dilakukan tindakan dalam dua siklus dapat dilihat perbandingan nilai ratarata yang diperoleh, dimana pada awalnya nilai rata-rata siswa hanya 69,83 naik di siklus I menjadi 74,67 dan di siklus II naik menjadi 75,64. Kenaikan ini merupakan upaya maksimal yang peneliti laksanakan untuk meningkatkan prestasi belajar Matematika siswa terutama meningkatkan mutu pendidikan di SMP Negeri 3 Selat. Tanpa harus berkutat di institusi pendidikan formal, orang tua maupun guru bisa membuat media yang mengajak anak belajar sambil bermain (Aripin, 2015).

\section{Kesimpulan}

Berdasarkan analisis data dapat disimpulkan sebagai berikut. 1) Nilai rata-rata awal 69,83 naik menjadi 74,67 pada siklus I dan pada siklus II naik menjadi 75,64. 2) Dari data awal siswa yang tuntas hanya 14 orang sedangkan pada siklus I menjadi lebih banyak yaitu 20 siswa dan pada siklus II menjadi cukup banyak yaitu 25 siswa. Paparan di atas membuktikan bahwa penerapan model Ekspository dengan metode demontrasi dan pemberian tugas sangat efektif diterapkan dalam pembelajaran Matematika yang mengakibatkan siswa aktif, antusias, berpikir kritis dan dapat memahami materi yang diajarkan sehingga prestasi belajar siswa menjadi meningkat. Adapun saran-saran yang akan diajukan sebagai berikut. (1) Siswa diharapkan dapat memanfaatkan model pembelajaran Ekspository dengan metode demontrasi dan pemberian tugas untuk meningkatkan prestasi belajarnya, khususnya pada mata pelajaran Matematika. (2) Guru yang ingin menerapkan model Pembelajaran Ekspository dengan metode demontrasi dan pemberian tugas, disarankan untuk mencermati kelemahan-kelemahan ataupun kekurangan-kekurangan yang ditemukan pada penelitian ini. (3) Sekolah khususnya SMP Negeri 3 Selat hasil penelitian ini dapat dijadikan bahan pertimbangan dalam pengembangan model dalam pembelajaran. (4) Peneliti lain dapat menjadikan hasil penelitian ini sebagai kajian penelitian yang relevan.

\section{Daftar Pustaka}

Dimyati dan Mudjiono. 2001. Belajar dan Pembelajaran. Jakarta: Dirjen Dikti. 
Djamarah, Syaful Bahri. 2002. Prestasi Belajar dan Kompetensi Guru. Surabaya: Usaha Nasional.

Hamalik, Oemar. 2002. Psikologi Belajar dan Mengajar. Bandung: Sinar Baru.

Herhyanto, Nar dan Hamid, Akib. 2006. Statistika Dasar. Jakarta: Universitas Terbuka.

Haryadi, T., \& Aripin, A. (2015). Melatih Kecerdasan Kognitif, Afektif, dan Psikomotorik Anak Sekolah Dasar Melalui Perancangan Game Simulasi "Warungku." ANDHARUPA: Jurnal Desain Komunikasi Visual $\mathcal{E}$ Multimedia. https:// doi.org/10.33633/andharupa.v1i02.963

Kurniawan, D., \& Wustqa, D. U. (2014). Pengaruh Perhatian Orang Tua, Motivasi Belajar dan Lingkungan Sosial Terhadap Prestasi Belajar Mate-matika Siswa SMP. Jurnal Riset Pendidikan Matematika. https://doi.org/10.21831/jrpm.v1i2.2674

Nurhidayah, D. A. (2015). Pengaruh Motivasi Berprestasi Dan Gaya Belajar Terhadap Prestasi Belajar Siswa Pada Mata Pelajaran Matematika Smp. Jurnal Dimensi Pendidikan dan Pembelajaran. https://doi.org/10.2426/dpp.v3i2.

Pardomuan Nauli Josip Mario, \& Sinambela. (2013). Kurikulum 2013 Dan Implementasinya Dalam Pembelajaran. e-journal Universitas Negeri Medan.

Rosa, F. O. (2015). Analisis Kemampuan Siswa Kelas X pada Ranah Kognitif , Afektif dan Psikomotorik. Jurnal Fisika dan Pendidikan Fisika. https:/ / doi.org/10.3233/JAD-2012111799

Sudjana, N. (2009). Penilaian Hasil Proses Belajar Mengajar. In Sinarbaru.

Widayati, A. (2014). Penelitian Tindakan Kelas. Jurnal Pendidikan Akuntansi Indonesia. https:// doi.org/10.21831/jpai.v6i1.1793 